\title{
Listening Skills: Important but Difficult to Learn
}

\author{
Jwahir Alzamil \\ English Language Centre \\ Taif University, Saudi Arabia
}

Received: 5/8/2021

Accepted: 8/9/2021

Published:9/24/2021

\begin{abstract}
This study of 87 Saudi female university students aimed to discover whether they experience difficulties learning to listen to spoken English. Acknowledging that listening is an important part not just of learning a new language but also of day-to-day communication, data was collected using an online questionnaire. Participants were asked to respond to a series of statements designed to test four constructs relating to their attitudes to learning English language skills in general (a); learning listening skills specifically (b); their attitudes towards listening activities (c); and (d) their attitudes towards improving their listening skills. The results showed that most of participants felt that speaking and listening were the most important skills to learn, but listening was also the most challenging. Reading was felt to be the most effortless skill to learn, as well as the most commonly used, suggesting that frequency of use contributes to students' perceptions of the ease of learning a skill. Participants' difficulties with learning to listen to English were associated with speech rate, pronunciation, nervousness, limited vocabulary, and lack of background information. However, students also expressed positive attitudes towards improving their listening skills. Understanding students' attitudes to listening skills and their problems with listening may help teachers improve the way they teach these skills. This may in turn improve students' listening comprehension not only in universities but also in schools.
\end{abstract}

Keywords: English teaching, learning difficulties, listening skills, Saudi students

Cite as: Alzamil, J. (2021). Listening Skills: Important but Difficult to Learn. Arab World English Journal, 12 (3) 366-374. DOI: https://dx.doi.org/10.24093/awej/vol12no3.25 


\section{Introduction}

Language is an important channel of communication through which we share our feelings and thoughts with others (Nishanthi, 2018). English is the most widely used and most influential language globally, and its importance cannot be denied (Nishanthi, 2018). Perhaps as a result, English teaching methods have become a subject of study for many academic researchers, especially in Saudi Arabia; teaching programmes and strategies, curricula, and students' attitudes towards learning have all become a focus of attention (Alhmadi, 2014).

Among the four key skills in English - writing, speaking, reading and listening - the ability to listen well, which is the focus of this paper, is very important because it can help improve other skills significantly (Darti \& Asmawati, 2017). Learners who speak English as a Foreign Language (EFL) need to listen to the English language daily if they want to communicate appropriately (Darti \& Asmawati, 2017). 'Development of listening skills is important for second language (L2) acquisition'(Kajiura, et al., 2021, p.1). In fact, it may not be possible to acquire the English language without listening as it provides second language learners with language input, which in turn plays a crucial role in language development (Darti \& Asmawati, 2017; Gilakjani \& Ahmadi, 2011). But because listening demands concentration, and English pronunciation is not consistent, listening is often considered to be the most challenging language skill to learn (Abdalhamid, 2012; Darti \& Asmawati, 2017; Gilakjani \& Ahmadi, 2011; Sa'diyah, 2016).

This study was therefore designed to address a series of related questions about Saudi female students' attitudes to acquiring English skills, with a particular focus on listening:

a. How do Saudi female students feel about the different skills required to learn English?

b. Do Saudi female university-level students experience difficulties when listening to English?

c. How do Saudi female students' feel about English language listening activities?

d. What are Saudi female students' attitudes towards improving their listening skill?

These questions are important and answers to them will provide teachers and curriculum planners in Saudi Arabia with information to help them improve their English teaching methods, which will help students improve their listening skills.

\section{Literature Review}

In daily life, listening is an everyday activity that has an important role in receiving information (Nushi \& Orouji, 2020). Rost (2013) stated that listening refers to a complex process that allows people to comprehend spoken language. Not only is it an essential element of producing effective communication, it also helps people to understand the world (Rost 2013). Understanding does not depend just on what speakers say, as listeners have a vital role in understanding the listening process by applying their knowledge to what they hear to understand what speakers mean (Anderson, Anderson, \& Lynch, 1988). However, there are several factors that may affect listeners, some of which they may not be able to control such as the background noise which may reduce listening comprehension (Sahlen, et al., 2020). Listeners are not able, for example, to influence the rate at which a speaker speaks, and may not be able to get them to repeat particular words or phrases. Moreover, the size of a learner's vocabulary can play a significant role in the listening process, since a restricted language will undermine comprehension. Finally, a speaker's use of signals or words as they move from one point to another may not be familiar to listeners (Underwood, 1989). 
Hamouda (2013) studied the listening problems encountered by Saudi students of English. Data was collected from a sample of 60 male students on the first year of an English degree course, at Qassim University, who were interviewed and asked to fill in a questionnaire. Hamouda concluded from his investigation that students find it very difficult to learn the listening skill. In fact, they encountered a range of problems in comprehending listening texts which were due to anxiety, pronunciation, speed of speech, their own poor vocabulary and mastery of grammar, speakers' accents, lack of concentration, and poor quality recordings. Moreover, students' listening performance was also hampered by the listening material and the environment. These results indicate that there is a range of factors that can affect students' listening performance. Some of these can be controlled by the teacher (material, environment), but others indicate that students need more practice to improve their listening comprehension.

Assaf (2015) conducted a similar study with 189 EFL university students studying at the English Language Centre at the Arab American University in Palestine, who were also interviewed and asked to complete a questionnaire. His results revealed that students face several difficulties with understanding while listening, such as not having enough information about the topic, not enjoying the listening text, noise, poor quality listening equipment, and speech rate.

Another similar study, of 30 EFL Sudanese university students, by Mahmoud and Ahmed (2020) also investigated listening difficulties. Having collected their data utilizing a questionnaire, Mahmoud and Ahmed found that students encountered listening difficulties with both understanding informal words and idiomatic expressions, and understanding listening texts which contained complicated grammatical structures. Students also found it challenging to comprehend a listening task the first time they heard it, and complained that they lacked concentration.

Rakhman, Tarjana, and Marmanto (2020) conducted a case study of the listening difficulties encountered by six Indonesian English Department Freshman students (aged 19-20) in their listening classes. Collecting their data using questionnaires, interviews, and observation, Rakhman et al. found that the students encountered several difficulties when listening to English, including problems with short-term memory, homophones and speech rate.

The studies discussed above show that EFL students frequently experience a range of difficulties with listening comprehension. However, there has been no study to date of the listening difficulties experienced by female Saudi Arabian students enrolled on their foundation year. This study aims to fill that gap in the literature.

\section{Methods \\ Participants}

The study collected data from a random sample of 87 Saudi female university students (aged 18-20) who had studied English for an average of eight years and were enrolled on their foundation year at a Saudi university.

\section{Research Instruments}

The data collection instrument was an online five-point Likert scale questionnaire which was used to obtain the students' views on the difficulties they encountered when listening to the 
English language. The questionnaire, which contained 20 items, was primarily adapted from Assaf (2015). Consisting of four sections, closed-ended questions were asked about students' attitudes to English language skills in general, as well as listening skills, listening activities, and improving listening skills. This attitudinal survey used a five-point Likert scale (strongly disagree to strongly agree). This method is easy for participants to complete, and is reliable (Bertram, 2006).

\section{Research Procedures}

Due to Covid-19, the questionnaire had to be administered online. Ethical issues are just as important in online research as in face-to-face research, and after obtaining permission from the university to carry out the study, participants were given information about the purpose of the research, reassured about confidentiality and anonymity and informed that they were free to withdraw from the research at any time if they wished. All the participants who responded to the questionnaire also completed consent forms.

\section{Results}

This section presents descriptive statistics for the questionnaire results, which are divided into the following four categories in line with the themes of the questions themselves: (a) participants' opinions about English skills generally; (b) their opinions about listening skills; (c) their opinions about listening activities; (d) their opinions about improving their listening skills. Each of the four tables below reports participants' opinions for each category.

Table 1. Questionnaire responses (questions 1-4)

\begin{tabular}{lcccc}
\multicolumn{1}{c}{ Question } & Reading & Writing & Listening & Speaking \\
\hline Q.1 Which of the following English & $7 / 87$ & $10 / 87$ & $21 / 87$ & $49 / 87$ \\
skills is most important to learn? & $8 \%$ & $11.5 \%$ & $24.1 \%$ & $56.3 \%$ \\
\hline Q.2 Which of the following English & $8 / 87$ & $10 / 87$ & $48 / 87$ & $21 / 87$ \\
skills is most difficult to learn? & $9.2 \%$ & $11.5 \%$ & $55.2 \%$ & $24.1 \%$ \\
\hline Q.3 Which of the following English & $35 / 87$ & $29 / 87$ & $14 / 87$ & $9 / 87$ \\
skills is easiest to learn? & $40.2 \%$ & $33.3 \%$ & $16.1 \%$ & $10.3 \%$ \\
\hline Q.4 Which language skill do you use & $35 / 87$ & $11 / 87$ & $18 / 87$ & $23 / 87$ \\
most often? & $40.2 \%$ & $12.6 \%$ & $20.7 \%$ & $26.4 .5 \%$
\end{tabular}

Participants' answers to questions about their attitudes to English in general showed that they feel differently about each of the core English skills in terms of their difficulty, importance and use. Most participants thought that speaking and listening were the most important skills to learn, but also thought that listening skills were the most difficult, while reading was the easiest. Reading was also the most commonly used skill among participants.

Table 2. Questionnaire responses (statements 5-12)

\begin{tabular}{lcccccc} 
Question & $\begin{array}{c}\text { Strongly } \\
\text { disagree }\end{array}$ & Disagree & Uncertain & Agree & $\begin{array}{c}\text { Strongly } \\
\text { agree }\end{array}$ \\
\hline S.5 I like listening to spoken & $4 / 87$ & $1 / 87$ & $5 / 87$ & $44 / 87$ & $33 / 87$ \\
English language. & & $4.6 \%$ & $1.1 \%$ & $5.7 \%$ & $50.6 \%$ & $37.9 \%$ \\
\hline
\end{tabular}


Arab World English Journal (AWEJ) Volume 12. Number 3. September 2021

Listening Skills: Important but Difficult to Learn

Alzamil

\begin{tabular}{|c|c|c|c|c|c|}
\hline $\begin{array}{l}\text { S.6 Understanding spoken } \\
\text { English is difficult. }\end{array}$ & $\begin{array}{l}18 / 87 \\
20.7 \%\end{array}$ & $\begin{array}{l}2 / 87 \\
2.3 \%\end{array}$ & $\begin{array}{l}18 / 87 \\
20.7 \%\end{array}$ & $\begin{array}{l}23 / 87 \\
26.4 \%\end{array}$ & $\begin{array}{l}26 / 87 \\
29.9 \%\end{array}$ \\
\hline $\begin{array}{l}\text { S.7 It is important to understand } \\
\text { spoken English language as } \\
\text { easily as native speakers of } \\
\text { English. }\end{array}$ & $\begin{array}{l}3 / 87 \\
3.4 \%\end{array}$ & $\begin{array}{l}4 / 87 \\
4.6 \%\end{array}$ & $\begin{array}{l}18 / 87 \\
20.7 \%\end{array}$ & $\begin{array}{l}35 / 87 \\
40.2 \%\end{array}$ & $\begin{array}{l}27 / 87 \\
31 \%\end{array}$ \\
\hline $\begin{array}{l}\text { S.8 I find it difficult to } \\
\text { understand English words while } \\
\text { listening. }\end{array}$ & $\begin{array}{l}8 / 87 \\
9.2 \%\end{array}$ & $\begin{array}{l}19 / 87 \\
21.8 \%\end{array}$ & $\begin{array}{l}13 / 87 \\
14.9 \%\end{array}$ & $\begin{array}{l}24 / 87 \\
27.6 \%\end{array}$ & $\begin{array}{l}23 / 87 \\
26.4 \%\end{array}$ \\
\hline $\begin{array}{l}\text { S.9 I find it difficult to } \\
\text { understand spoken English when } \\
\text { English speakers speak fast. }\end{array}$ & $\begin{array}{l}4 / 87 \\
4.6 \%\end{array}$ & $\begin{array}{l}6 / 87 \\
6.9 \%\end{array}$ & $\begin{array}{l}12 / 87 \\
13.8 \%\end{array}$ & $\begin{array}{l}43 / 87 \\
49.4 \%\end{array}$ & $\begin{array}{l}22 / 87 \\
25.3 \%\end{array}$ \\
\hline $\begin{array}{l}\text { S.10 I feel nervous when } \\
\text { listening to an English speaker's } \\
\text { speech. }\end{array}$ & $\begin{array}{l}11 / 87 \\
12.6 \%\end{array}$ & $\begin{array}{l}6 / 87 \\
6.9 \%\end{array}$ & $\begin{array}{l}13 / 87 \\
14.9 \%\end{array}$ & $\begin{array}{l}35 / 87 \\
40.2 \%\end{array}$ & $\begin{array}{l}22 / 87 \\
25.3 \%\end{array}$ \\
\hline S.11 I enjoy listening classes. & $\begin{array}{l}1 / 87 \\
1.1 \%\end{array}$ & $\begin{array}{c}14 / 87 \\
16.1 \% \\
\end{array}$ & $\begin{array}{c}18 / 87 \\
20.7 \% \\
\end{array}$ & $\begin{array}{l}38 / 87 \\
43.7 \% \\
\end{array}$ & $\begin{array}{c}16 / 87 \\
18.4 \% \\
\end{array}$ \\
\hline $\begin{array}{l}\text { S12. It is more difficult to } \\
\text { understand spoken English when } \\
\text { the speaker is a native English }\end{array}$ & $\begin{array}{c}7 / 87 \\
8 \%\end{array}$ & $\begin{array}{c}6 / 87 \\
6.9 \%\end{array}$ & $\begin{array}{c}15 / 87 \\
17.2 \%\end{array}$ & $\begin{array}{c}34 / 87 \\
39.1 \%\end{array}$ & $\begin{array}{c}25 / 87 \\
28.7 \%\end{array}$ \\
\hline
\end{tabular}

speaker.

In terms of their attitudes to listening, most participants found it difficult to understand while listening to English speakers, mainly when they spoke fast. Most also experienced nervousness about listening to English and felt that it was harder to understand native English speakers. This indicates that participants encountered problems when listening to the English language.

Table 3. Questionnaire responses (statements 13-17)

\begin{tabular}{lccccc}
\multicolumn{1}{c}{ Question } & $\begin{array}{c}\text { Strongly } \\
\text { disagree }\end{array}$ & Disagree & Uncertain & Agree & $\begin{array}{c}\text { Strongly } \\
\text { agree }\end{array}$ \\
\hline S.13 Listening activities & $12 / 87$ & $4 / 87$ & $4 / 87$ & $34 / 87$ & $33 / 87$ \\
improve my English. & $13.8 \%$ & $4.6 \%$ & $4.6 \%$ & $39.1 \%$ & $37.9 \%$ \\
\hline $\begin{array}{l}\text { S.14 I cannot concentrate when } \\
\text { doing a listening activity. }\end{array}$ & $8 / 87$ & $13 / 87$ & $7 / 87$ & $29 / 87$ & $30 / 87$ \\
\hline S.15 I find it difficult to & $5 / 87$ & $14.9 \%$ & $8 \%$ & $33.3 \%$ & $34.5 \%$ \\
understand listening activities & $5.7 \%$ & $14.9 \%$ & $9.2 \%$ & $55.2 \%$ & $14.9 \%$ \\
when the topics are unfamiliar. & & & & \\
\hline S.16 I feel nervous when doing & $10 / 87$ & $22 / 87$ & $4 / 87$ & $25 / 87$ & $26 / 87$ \\
a listening activity. & $11.5 \%$ & $25.3 \%$ & $4.6 \%$ & $28.7 \%$ & $29.9 \%$ \\
\hline $\begin{array}{l}\text { S.17 It bothers me when an } \\
\text { English teacher focuses on }\end{array}$ & $24 / 87$ & $24 / 87$ & $15 / 87$ & $20 / 87$ & $4 / 87$ \\
listening activities. & $27.6 \%$ & $27.6 \%$ & $17.2 \%$ & $23 \%$ & $4.6 \%$
\end{tabular}


Statements 13 to 17 asked participants to rate their attitudes towards English listening activities. Participants largely found listening activities to be helpful (S13) and more than half understood that listening is important for improving their English (S17). However close to $70 \%$ of participants also indicated that they found it difficult to concentrate on listening tasks (S14), while a similar number agreed that it was difficult to understand unfamiliar topics presented in English (S15).

Table 4. Questionnaire responses (statements 18-20)

\begin{tabular}{lccccc}
\multicolumn{1}{c}{ Question } & $\begin{array}{c}\text { Strongly } \\
\text { disagree }\end{array}$ & Disagree & Uncertain & Agree & $\begin{array}{c}\text { Strongly } \\
\text { agree }\end{array}$ \\
\hline $\begin{array}{l}\text { S.18 I want my teacher to focus } \\
\text { on listening skills all the time. }\end{array}$ & $5 / 87$ & $20 / 87$ & $13 / 87$ & $21 / 87$ & $28 / 87$ \\
\hline S.19 To improve my listening & & $23 \%$ & $14.9 \%$ & $24.1 \%$ & $32.2 \%$ \\
skills, I need to listen to the & $5 / 87$ & $1 / 87$ & $6 / 87$ & $42 / 87$ & $33 / 87$ \\
English language outside & $5.7 \%$ & $1.1 \%$ & $6.9 \%$ & $48.3 \%$ & $37.9 \%$ \\
university. & & & & & \\
\hline $\begin{array}{l}\text { S.20 Listening to native } \\
\text { speakers of English improves }\end{array}$ & $2 / 87$ & $10 / 87$ & $20 / 87$ & $23 / 87$ & $32 / 87$ \\
my English listening skills. & $2.3 \%$ & $11.5 \%$ & $23 \%$ & $26.4 \%$ & $36.8 \%$
\end{tabular}

Most participants either agreed or strongly agreed with Statement 19, an indication that they felt it was important to practise listening outside the classroom to improve their English.

\section{Discussion}

Participants' responses to the questionnaire give a helpful indication of how they feel about learning English in general, and more importantly how they feel about learning the key skill of listening. The statements were grouped into four categories - a) opinions about English skills generally; b) opinions about the listening skill; c) opinions about listening activities; and d) opinions about improving their listening skill. These are discussed in turn below.

Regarding their attitudes towards learning English in general, most participants (56.3\%) thought that speaking was the most important skill. Listening was ranked as the most important skill to learn by $24.1 \%$ of participants. However, these positions were reversed when participants were asked to consider the difficulty of learning the different skills. Listening was regarded as the most difficult skill to learn by more than half of participants $(55.2 \%)$, while only $24.1 \%$ voted for speaking as most difficult to learn. Meanwhile, reading English was the most frequently used skill, and considered to be the most effortless to learn by approximately $40 \%$ of participants. These findings suggest that participants' rating of the level of difficulty of a skill was related to the level of importance they attributed to that skill. That is why listening was highly ranked concerning its level of importance (second place) as well as in terms of its difficulty (first place). Conversely, the most commonly used skill - reading - was also the skill that participants found easiest to learn. This shows the importance of practice and frequent use for making a skill easy to use. 
Concerning the statements in the second category, which asked participants for their opinions about listening skills, a large majority enjoyed listening to spoken English. Most also expressed a positive attitude towards listening classes. Apart from this, the results support the findings of Hamouda (2013), Assaf (2015), and Rakhman, Tarjana, and Marmanto (2020) by showing that participants faced difficulties with listening to English, due to pronunciation, the speed at which speakers spoke, anxiety and their poor mastery of vocabulary. The participants' attitudes highlight the need for teachers to focus on improving students' listening skill.

In terms of their attitudes to learning listening skills, responses to Statement 14 - 'I cannot concentrate when doing a listening activity' - support Mahmoud and Ahmed (2020). Close to $70 \%$ of participants found it difficult to concentrate when listening to English language activities. Moreover, the findings of statement 15 support Assaf (2015): students found it difficult to understand while listening if they did not have enough information about topics. Overall, participants agreed that listening activities help them improve their English, but despite these positive attitudes towards listening activities and their benefits, students still found listening difficult. This indicates that the provision of English listening activities during classes is essential, to improve their listening skill.

In their responses to the statements in the fourth category, participants indicated that they had positive attitudes towards listening to English outside university and listening to native speakers as ways to improve their listening skills. This indicates that participants would like to improve their listening skill and think that it is important to focus on listening activities. When students have positive attitudes, this may lead to the desired level of learning.

Students' responses to the statements in all four categories show that they think listening is a crucial skill (second only to speaking). Yet at the same time as they think listening to be essential, students also find listening activities difficult. Because of this, and because hearing spoken English helps students acquire vocabulary and comprehension skills, it is really crucial for students to learn to listen well. Students therefore need to be provided with English listening activities in the classroom.

This study was limited to the extent that its focus of concern was students' attitudes to listening, while ignoring problems they may have in acquiring the other key English language skills. Future research should therefore look at whether students also face difficulties when learning to read, write and speak - and if so - what these difficulties might be. The study was also limited by its exclusive focus on females; future research should include males too.

\section{Conclusion}

Students' attitudes play an essential role in learning English. In fact, knowing their attitudes and the problems they face in acquiring English language skills may help teachers develop effective strategies for their students, which in turn may improve their skills. Most of the participants in this study feel that speaking and listening are the most crucial skills to learn, while listening was also ranked as the most challenging. The most commonly used skill, reading English, was also felt to be the most effortless to learn. The study's results also show that students face some challenges when learning to listen to English, due to the speaker's pronunciation and speed, and their own anxiety and poor mastery of vocabulary as well as lack 
of information about the topics of speech. However, students did express positive attitudes towards improving their listening skill. These results suggest that to improve their listening skills effectively and overcome these problems, it is really important for students of English to listen to the language as it is spoken, not just in the classroom but also at home.

\section{About the Author:}

Dr. Jwahir Alzamil is an assistant professor of applied linguistics in the English Language Centre at Taif University, Saudi Arabia. Her research interests centre around applied linguistics. https://orcid.org/0000-0002-6632-3924

\section{References}

Abdalhamid, F. (2012). Listening comprehension strategies of Arabic-speaking ESL learners, (Unpublished Master's dissertation). Department of English, Colorado State University, Fort Collins, Colorado.

Alhmadi, N. S. (2014). English speaking learning barriers in Saudi Arabia: A case study of Tibah University. Arab World English Journal, 5(2) 38-53. https://awej.org/englishspeaking-learning-barriers-in-saudi-arabia-a-case-study-of-tibah-university/

Anderson, A. C., Anderson, A., \& Lynch, T. (1988). Listening. Oxford: Oxford University Press.

Assaf, A. H. (2015). The difficulties encountered by EFL learners in listening comprehension as perceived by ELC students at the Arab American University-Jenin, (Published Master's Thesis). An-Najah National University: Nablus, Palestine.

Bertram, D. (2006). Topic Report: Likert Scales, Computer Science and Engineering. Texas A \& M University.

Darti, D., \& Asmawati, A. (2017). Analyzing students' difficulties toward listening comprehension. English, Teaching, Learning, and Research Journal, 3(2) 211-228. https://doi.org/10.24252/Eternal.V32.2017.A9

Gilakjani, A. P., \& Ahmadi, M. R. (2011). A study of factors affecting EFL learners' English listening comprehension and the strategies for improvement. Journal of Language Teaching and Research, 2(5), 977-988. https://doi.org/10.4304/jltr.2.5.977-988

Hamouda, A. (2013). An investigation of listening comprehension problems encountered by Saudi students in the EL listening classroom. International Journal of Academic Research in Progressive Education and Development, 2(2), 113-155.

Kajiura, M., Jeong, H., Kawata, N. Y., Yu, S., Kinoshita, T., Kawashima, R., \& Sugiura, M. (2021). Brain Activity Predicts Future Learning Success in Intensive Second Language $\begin{array}{llll}\text { Listening Training. } & \text { Brain }\end{array}$ https://doi.org/10.1016/j.bandl.2020.104839

Mahmoud, T. O. M., \& Ahmed, M. A. (2020). Investigating teacher's views and perceptions about listening comprehension difficulties encountered by Sudanese university students. Journal of Linguistic and Literary Studies, 21(2), 91-100.

Nishanthi, R. (2018). Important of learning English in today world. International Journal of Trend in Scientific Research and Development, 3(1), 871-874. doi:10.31142/ijtsrd19061

Nushi, M., \& Orouji, F. (2020). Investigating EFL Teachers' Views on Listening Difficulties Among Their Learners: The Case of Iranian Context. SAGE Open, 10(2), 1-16. https://doi.org/10.1177/2158244020917393 
Rakhman, F. A., Tarjana, S. S., \& Marmanto, S. (2020). Indonesian English Department Students Listening Difficulties and Listening Strategies. IJER (Indonesian Journal of Educational Research), 4(2), 60-67.

Rost, M. (2013). Teaching and Researching: Listening. London: Routledge. https://doi.org/10.4324/9781315833705

Sa'diyah, S. S. (2016). EFL learners faced problems in listening comprehension. Indonesian EFL Journal, 2(1), 53-59. https://doi.org/10.25134/ieflj.v2i1.637

Sahlen, B., Brannstrom, K. J., Lyberg Ahlander, V., \& Rudner, M. (2020). Children Listen: Psychological and Linguistic Aspects of Listening Difficulties During Development. Frontiers in Psychology, 11. https://doi.org/10.3389/fpsyg.2020.584034

Underwood, M. (1989). Teaching Listening. New York: Longman. 